\title{
Magnetic Study of the Heated and Unheated Sedimentary Fillings of Sebkha Mhabeul, Southeast Tunisia: A Geophysical Method for Paleoclimatic Investigation and Tephrochronological Dating
}

\author{
Elhoucine Essefi, ${ }^{1,2,3}$ Samir Mefteh, ${ }^{4,5}$ Mounir Medhioub, ${ }^{4}$ and Chokri Yaich ${ }^{1,2,3}$ \\ ${ }^{1}$ National Engineering School of Sfax, Road of Soukra, km 4, 3038 Sfax, Tunisia \\ ${ }^{2}$ University of Sfax, Road of the Airport, $\mathrm{km}$ 0.5, 3029 Sfax, Tunisia \\ ${ }^{3} R U$ : Sedimentary Dynamics and Environment (DSE) (Code 03/UR/10-03), National Engineering School of Sfax, \\ University of Sfax, Road of Soukra, km 4, 3038 Sfax, Tunisia \\ ${ }^{4}$ Département des Sciences de la Terre, Faculté des Sciences de Sfax (FSS), Route de Soukra, Km 3.5, BP 802, 3018 Sfax, Tunisia \\ ${ }^{5}$ Laboratoire de Valorisation des Matériaux Utiles, CNRSM, Technopole de Borj Cedria, BP 273, 8020 Soliman, Tunisia
}

Correspondence should be addressed to Elhoucine Essefi; hocinsefi@yahoo.fr

Received 18 January 2014; Revised 29 May 2014; Accepted 29 May 2014; Published 19 June 2014

Academic Editor: Marek Grad

Copyright (C) 2014 Elhoucine Essefi et al. This is an open access article distributed under the Creative Commons Attribution License, which permits unrestricted use, distribution, and reproduction in any medium, provided the original work is properly cited.

This paper is meant to investigate the climatic and volcanic signals within the sedimentary filling of sebkha Mhabeul through a thermomagnetic study of a $37 \mathrm{~cm}$ length core. Values of the magnetic susceptibility at ambient temperature show that the core encompasses four climatic stages: the Warming Present (WP), the Little Ice Age (Late LIA), Early Little Ice Age (ELIA), and the Medieval Climate Anomalies (MCA). Added to the subcycles, the spectral analysis shows the individualization of an $888 \mathrm{yr}$ cycle probably related to solar activity. The heating at $250^{\circ} \mathrm{C}$ is good-for-nothing since it was useful neither for climatic investigation nor for tephras layers detection. Heating at $700^{\circ} \mathrm{C}$ generated the complete loss of the climatic signal. On the other hand, it allowed the detection of the previously identified tephras layers. Further, it highlighted the presence of other tephras layers. The extraction by the bromoform confirms the presence of these tephras. The use of the same methodology may allow the detection of tephras layers within other sebkhas.

\section{Introduction}

Within lakes and playas, the magnetic susceptibility may have paleoclimatic [1] as well as volcanic significance [2]. Climatically, during humid climate phase, high-level lake, or groundwater rise, the sedimentation is governed by paramagnetic aeolian sediment coming from far regions [1]. The vicinities of the playa are consolidated and aeolian sedimentation rich with diamagnetic minerals is limited [3]. The effects of rainfall have been widely reported as an important causal factor in the magnetic enhancement of paleosols [4-6]. On the other hand, during arid climate phase, the geochemical sedimentation of diamagnetic minerals [1] enhanced by a fall of playa level and groundwater, which in turn enhanced the erodibility of sediment rich in evaporites within the watershed [3]. So, high and moderate values of the magnetic susceptibility are attributed to humid climate phase. The aridity is linked to low values caused by geochemical sedimentation of diamagnetic minerals. Based on the alternation of high and low values of the magnetic susceptibility, the spectral analysis allows the identification of individualized cycles $[7,8]$.

In spite of some pitfalls and problems, tephrochronology is one of the few geochronological methods that offer a temporal and spatial precision to link and date geological, palaeoecological, palaeoclimatic, or archaeological sequences or events [2]. The method critically relying on the stratigraphy and the Law of Superposition [9] requires the characterization and identification of tephra layers of 
well-known volcanic eruptions. The use of this method is strongly motivated by the greatest value provided, especially when a numerical age is obtained for a tephras layer by one or more dating methods. The obtained numerical ages may be recurrently transferred from one site to another using stratigraphic methods and by correlating compositional characteristics of each tephras layer. In lakes and playas, once dated, the tephras layers may be successfully used to provide a chronological framework for the sedimentary lacustrine records of climatic or environmental changes [1013]. Nonetheless, tephrochronology faced many technical handicaps for its applicability in both volcanic and nonvolcanic regions. In the volcanic regions, tephras are ubiquitous and easily identifiable, unless they overlap and influence the climatic and ecologic signals [14]. In the nonvolcanic regions, if ever existed, tephras or cryptotephras are diluted within sediment and their signals are more than likely drowned within the signals of climatic variability. Accordingly, several nondestructive approaches may be used in the detection of microscopic tephras layers, such as magnetic susceptibility, spectrophotometry, and X-ray fluorescence [15]. Magnetic susceptibility measurements [16] enabled relatively rapid and inexpensive systematic searching of tephras. Since basalt is strongly magnetic, previous studies have demonstrated that basaltic tephra horizons can sometimes be detected directly within sequences by systematic measurement of variations in the magnetic strength of sediments $[17,18]$. However, this method is not usually successful unless the shard sizes of the tephra particles are large. In this vein, [19] warned that high magnetic susceptibility values in lake sediments in their European study related to detrital magnetic minerals rather than tephra or cryptotephra layers; however, a finding echoed in part by [20]. As is the case in nonvolcanic regions, the concentration of the shards is usually too low for detection in bulk sediments by magnetic susceptibility measurements. For instance, the application of the magnetic susceptibility has failed to detect the microtephras layers known to be present in the Scottish LGIT sequences [21]. Additional experiments were run whereby the prepared samples were preheated in $50^{\circ} \mathrm{C}$ increments from room temperature to $650^{\circ} \mathrm{C}$. Heating can enhance the magnetic signal in paramagnetic materials by the generation of more magnetic minerals within the shards [22]. Systematic monitoring showed the enhanced signal to be stable for a period of at least seven days [23].

The aim of this paper is the study of the record of climatic oscillation and volcanic activity during the last millennium based on the magnetic susceptibility. The studied site was previously studied by [13]. But the climatic study was made in the shadow of the climatic cycle. Tephras layers were identified at $1.5 \mathrm{~cm}$ (olivine-diopside of Stromboli, AD 1930) and $9 \mathrm{~cm}$ (Augite-diopside of Vesuvius, December 17, AD 1631). In this study, detecting the well-known climatic events and tephras layers through the magnetic susceptibility will set the standard for other playas in Tunisia. In doing so, we will be able to detect the same climatic events and tephras layers through the same geophysical procedure. In addition, the spectral analysis is carried out to found climatic cycles based on the spectral analysis.

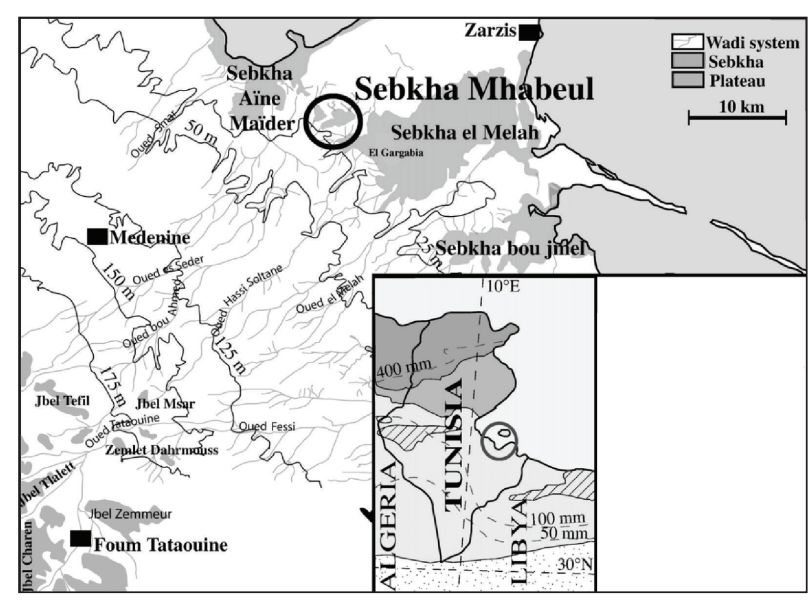

Mediterranean forest and maquis

Mediterranean steppeland

Semidesert vegetation with Artemisia, Ephedra, and Chenopodiaceae Desertic vegetation

Chenopodiaceae

- - - Isohyets of annual rainfall

Study area

FIGURE 1: Location of Sebkha Mhabeul in southeast Tunisia: vegetation belts and isohyets are indicated [13].

\section{Study Area}

The $4-\mathrm{km}^{2}$ sebkha Mhabeul is located on the northern edge of the coastal Djeffara plain (Figure 1). This 40-km-wide plain is covered with marine and lacustrine Quaternary deposits and bordered to the south by an escarpment of Mesozoic limestones [24]. The sebkha is disjointed from the eastern larger sebkha Melah by an accumulation of upper Pleistocene sediments, which avoids any connection of the former to the sea. Its sedimentation mode is mainly controlled by precipitation and runoff from small hydrographic networks $[25,26]$. The region is characterized by an arid climate imposing real desert conditions. According to the seasons, the temperatures and the rainfall considerably vary. The wet period of winter is marked by low temperatures ( 1 to $2^{\circ} \mathrm{C}$ ) of continental character. Oppositely, the dry period of the summer is characterized by excessive temperatures reaching sometimes $40^{\circ} \mathrm{C}$ in the shade. The total rainfall average is about $100 \mathrm{~mm} /$ year with significant variations from one month to another. The indexes of evaporation are at their highest level in July and August reflecting a noticeable correlation with the temperature variation. Depending on the season, the wind sector changes and sometimes blows with an instantaneous speed easily reaching $10 \mathrm{~m} / \mathrm{s}$. The winds of the wet period are generally from the west to east. Those, of the dry period, are rather from the $S$ to SSW. The latter are frequently accompanied with sirocco especially during June, July, and August. The studied site was previously studied by [13] to infer the climatic variability during the last millennia. 
This study was useful to correlate with other playas in Tunisia [27-29].

\section{Method and Material}

The $37 \mathrm{~cm}$ core was carried out in the location of the $65 \mathrm{~cm}$ core of [13]. Within laboratory, the sampling was carried out each $1 \mathrm{~cm}$. At ambient temperature $\left(25^{\circ} \mathrm{C}\right)$, the measurement of the magnetic susceptibility MS was done by the Bartington MS2B probe in the laboratory of Sedimentary Dynamics and Environment, National engineering School of Sfax. Samples were packed into $10 \mathrm{~cm}^{3}$ cylindrical perspex pots for MS analysis. After a heating to $700^{\circ} \mathrm{C}$ during 2 hours, samples were maintained in the ambient temperature for 24 hours. The effect of heating may be maintained to at least 7 days [23]. Then, the measurement of the magnetic susceptibility was repeated. As for data treatment, the spectral analysis and sinusoidal fitting were carried out through PAST software. Concerning the spectral analysis, PAST includes the Lomb periodogram algorithm for unevenly sampled data [30], with time values given in the first column and dependent values in the second column. The data are automatically detrended prior to analysis. The highest peak in the spectrum is presented with its frequency and power value, together with a probability that the peak could occur from random data. The 0.01 and 0.05 significance levels (white noise lines) are shown as red dashed lines. The extraction of tephras or cryptotephras from the 37 samples was carried out by means of the bromoform. The sediment was mixed with bromoform in an ampoule. Except heavy minerals, all fractions float away. The deposited fraction was washed and recuperated with alcohol.

\section{Results and Discussion}

4.1. Magnetic Study at the Ambient Temperature: Climatic Cyclicity. According to the age-depth model based on the tephrochronology [13], the mean rate of sedimentation during the last millennium is about $3.33 \mathrm{~mm} /$ year. Accordingly, the $37 \mathrm{~cm}$ core of the sebkha Mhabeul covers the last $1100 \mathrm{yr}$ (Figure 2). This time interval encompasses four climatic stages: the Warming Present (WP) [28, 29], the Little Ice Age (Late LIA) [31], Early Little Ice Age (ELIA), and the Medieval Climate Anomalies (MCA). First, in the uppermost part of the core $(3.5 \mathrm{~cm})$, the stage Warming Present (WP) stretches from present to 95 , that is, $\approx 95 \mathrm{yr}$; the establishment of modern conditions is characterised by stable conditions. Added to a small salt crust, this period is dominated by a clayey sedimentation rich with organic matter. Geophysically, we notice a downward increase of values of the magnetic susceptibility as indication of an increasing wetting and a decrease of the diamagnetic minerals coming from the in situ precipitation within the playa and aeolian sedimentation of the watershed. Second, the Late Little Ice Age (Late LIA) [31]; it stretches between the $95 \mathrm{yr}$ and $400 \mathrm{yr}$, that is, $305 \mathrm{yr}$. Along the depth between $3.5 \mathrm{~cm}$ and $23.5 \mathrm{~cm}$, the clayey sedimentation makes up the twofold and threefold laminates. Geophysically, this period itself is divided into different

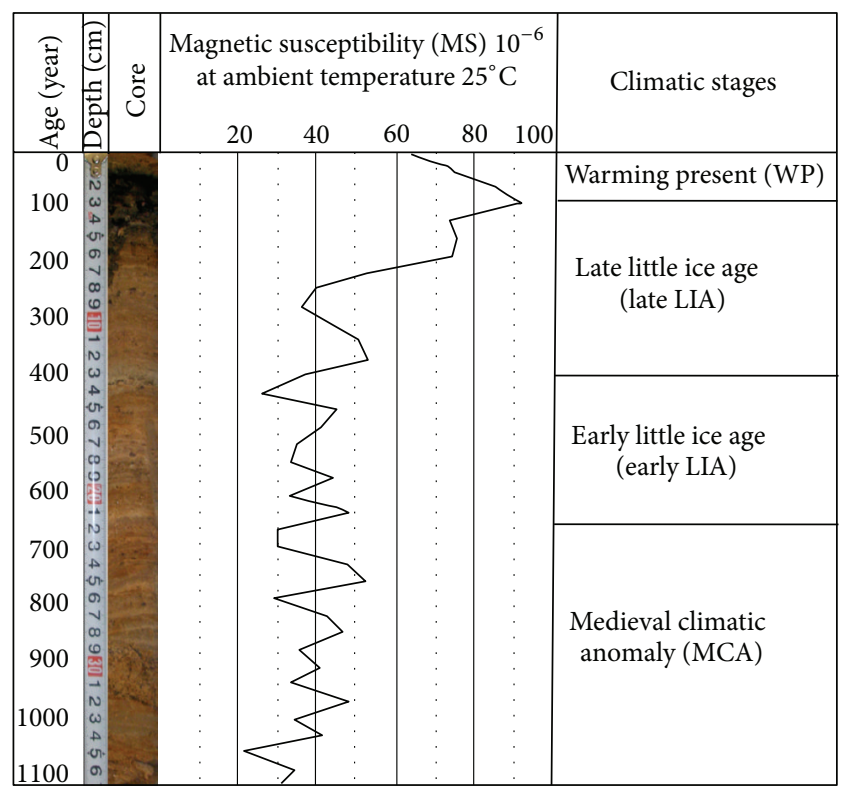

FIGURE 2: Magnetic values at the ambient temperature along the core from sebkha Mhabeul.

magnetic cycles. The first cycle ( 3.5 to 19.5 ) is dominated by a downward decrease of values of the magnetic susceptibility as indication of an increasing dryness and an increase of the diamagnetic minerals coming from the in situ precipitation within the playa and aeolian sedimentation of the watershed. Ferromagnetic minerals are quite limited due to a limited rainfall. In spite of a tendency toward an increase of values of MS, the second cycle may be also classified as dry, compared with the wet period taking place at end of WP. This Late LIA is a transition period between the wet period taking place at the end of WP and the dry conditions taking place in the ELIA and the MCA. Third, from ca. $400 \mathrm{yr}$ to $613 \mathrm{yr}$, the Early Little Ice Age (ELIA) shows moderate values of the magnetic susceptibility. Along this period, we did not record values lower than $30 \cdot 10^{-6}$. The climate is relatively wet, but stable. Fourth, the Medieval Climatic Anomaly (MCA) stretching from $613 \mathrm{yr}$ to 1100 is unstable and dry. The magnetic susceptibility shows an obvious tendency toward the decrease. The magnetic susceptibility may reach values lower than $30 \cdot 10^{-6}$.

Spectral analysis needs a precise dating. Although a more detailed age-depth model is available [13], and since the aim is to set the standard to study other playas in Tunisia, we worked with the average age-depth model because a detailed model is not always available in other playas in Tunisia. The spectral analysis of the values of the magnetic susceptibility at the ambient temperature (Figure 3) shows the appearance of an individualized frequency (0.0011261) having a peak (7.993) exceeding the $p(0.05)$ (7.03). Taking into account the average temporal spacing provided by the age-depth calculated from [13] $(33 \mathrm{yr} / \mathrm{cm})$, we found out a periodicity of $888 \mathrm{yr} \approx 1,000 \mathrm{yr}$. These variations occurred with periodicities similar to those of solar activity rather than orbital forcing. Actually, it is widely accepted that climate variability on time scales of 


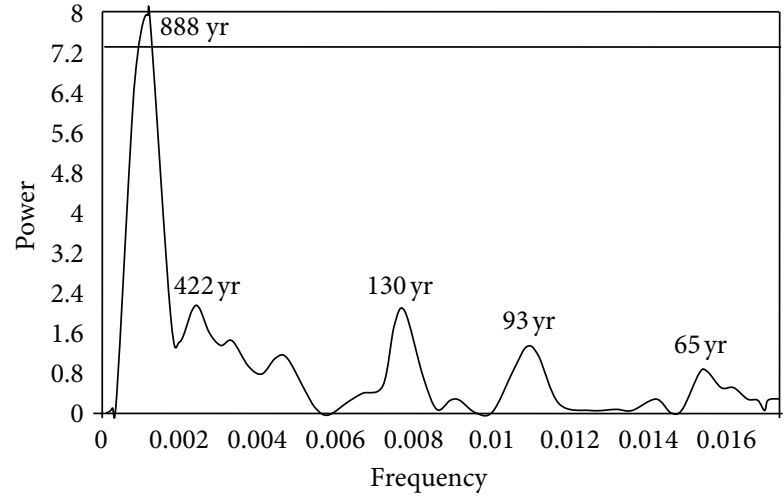

FIGURE 3: Spectral analysis of the magnetic susceptibility at the ambient temperature along the core from sebkha Mhabeul.

$10^{3}$ to $10^{5}$ years is basically driven by orbital, or so-called Milankovitch, forcing. Less well understood is the cause of the centennial to millennial variability [32]. Recently, millennialscale climate variability has been detected in several Holocene climate proxy records, but there is little consensus about the precise timing, amplitude, or cause of these fluctuations [32-34]. Furthermore, periodicities in the multidecadal to centennial mode were discussed by [35]. Other records, such as Holocene tree-ring 14C fluctuations, show similar significant periodicities [36] (206, 148, 87, and 46-49 years). Such periodicities may arise from fluctuations in solar activity and/or be the consequence of changes in thermohaline oceanic circulation. Less significant periods are also recoded (Figure 3).

4.2. Magnetic Susceptibility after Heating at $250^{\circ} \mathrm{C}$. The increase of the magnetic susceptibility is basically due to the formation of iron oxide. Exposed to fire events, sediments structure and content may be modified by removal of significant amounts of organic matter, deterioration of structure and porosity, considerable loss of nutrients through volatilization, increased sediment $\mathrm{pH}$ values, and alteration of sediment minerals $[37,38]$. Heat-induced sediment mineralogical changes may cause irreversible changes in the sediment mineral structure and composition, and they occur at a wide range of temperatures. At $250^{\circ} \mathrm{C}$ (Figure 4), the magnetic susceptibility slightly increases due to thermal agitation and mineralogical transformation. Due to thermal agitation, atomic spins are oriented parallel and the sediment translates from the paramagnetic, antiferromagnetic, and ferrimagnetic domains to the ferromagnetic domains. The thermal agitation is irreversible during a small period of time (7 days). Also, the mineralogical transformation is irreversible. The climatic signal previously distinguished by the magnetic susceptibility is no longer evident. A number of complicated and linked artificial transformations erases the climatic signal within sediment. On the other hand, signals of tephras layers are not quite individualized. This heating is good-for-nothing since it visualises neither the climatic variability nor tephras layers.

The spectral analysis of the magnetic susceptibility at $250^{\circ} \mathrm{C}$ along the core from sebkha Mhabeul (Figure 5) shows

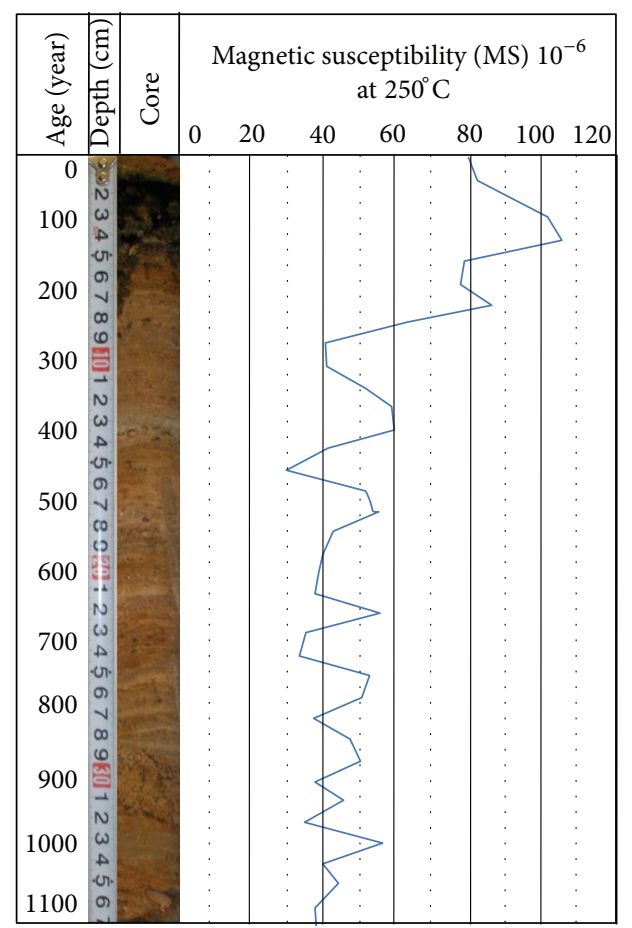

Figure 4: Magnetic values after heating to $250^{\circ} \mathrm{C}$ along the core from sebkha Mhabeul.

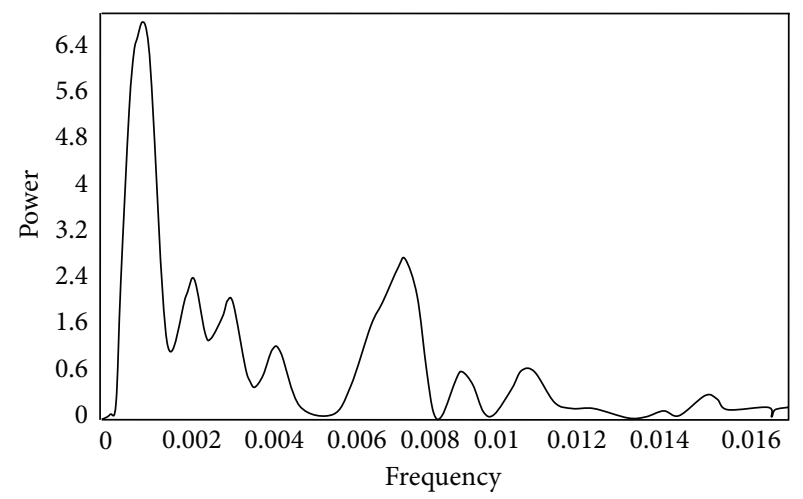

FIgURE 5: Spectral analysis of the magnetic susceptibility at $250^{\circ} \mathrm{C}$ along the core from sebkha Mhabeul.

a loss of the cyclicity. The frequency with high peak does not reach the threshold to find out an obvious periodicity. In addition, artifact frequency (0.0075) appears due the mineralogical transformation and the thermal agitation.

4.3. Magnetic Susceptibility after Heating at $700^{\circ} \mathrm{C}$. As complex as they were, the mineralogical transformations and the accompanied magnetic modifications are far from being straightforwardly described. These transformations overlap and the byproduct of one may be used as initial product of the other. To name but a few, the organic matter is totally destroyed due to the loss in ignition. The carbonates, which are diamagnetic minerals, are totally transformed. Also, we note the formation of magnetite nanoparticles by 


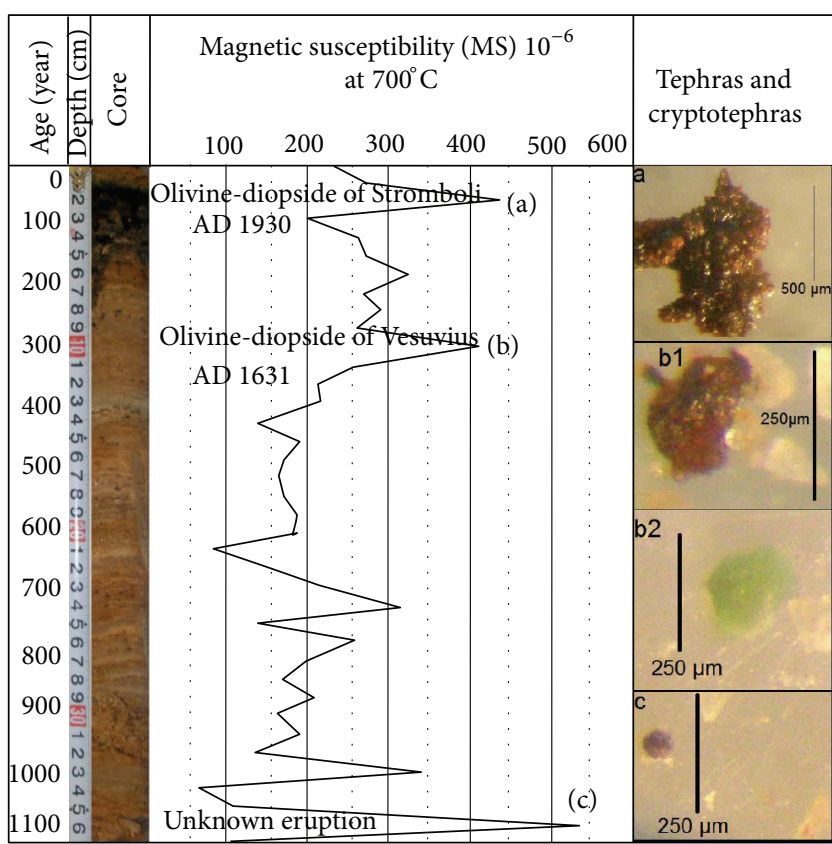

FIgURE 6: Magnetic susceptibility at $700^{\circ} \mathrm{C}$ along the core from sebkha Mhabeul: highlighting the signal of tephras layers.

thermal decomposition of iron bearing carbonates [39]. In this study, the deal is with experimental notification. The heating at $700^{\circ} \mathrm{C}$ results in the individualization of three obvious peaks along the profile of values of the magnetic susceptibility (Figure 6). Two known peaks are located at 1.5 and $9 \mathrm{~cm}$. The peak at $1.5 \mathrm{~cm}$ is due to the presence of tephras layers (olivine-diopside of Stromboli, AD 1930). The peak at $9 \mathrm{~cm}$ is due to the presence of tephras layers (Augite-diopside of Vesuvius, December 17, AD 1631). These layers were recently identified and dated by [13]. Located at $36 \mathrm{~cm}$, the third peak remains unknown. According to the age-depth model, this unknown eruption would have taken place approximately thousand years ago. As a matter of fact, [13] mentioned the presence of nondated tephras layers in sebkha Mhabeul. Undoubtedly, the magnetic tool would not go far to investigate geochemical and mineralogical details. Nonetheless, detecting the presence of tephras layers by this quick analysis may be used to investigate the presence of tephras in other locations in the standard core of sebkha Mhabeul. The extraction by the bromoform confirms the presence of these tephras (Figure 6), which may be attributed to one of the volcanic eruptions taking place between $1100 \mathrm{AD}$ and $1300 \mathrm{AD}[40]$.

As it is shown in Figure 7, heating at $700^{\circ} \mathrm{C}$ completely destroyed the periodicity inherited from the climatic variability. After heating, the original mineralogical compositions of sediment undergo noticeable transformations. The magnetic signal inherited from the paleoenvironmental conditions is no longer preserved. The pitfall of heating lies in the loss of the climatic signal. On the other hand, it allows highlighting the volcanic signal through the identification of tephras layers.

As it is shown in Table 1, heating progressively increased the values of the magnetic susceptibility. Also, heating

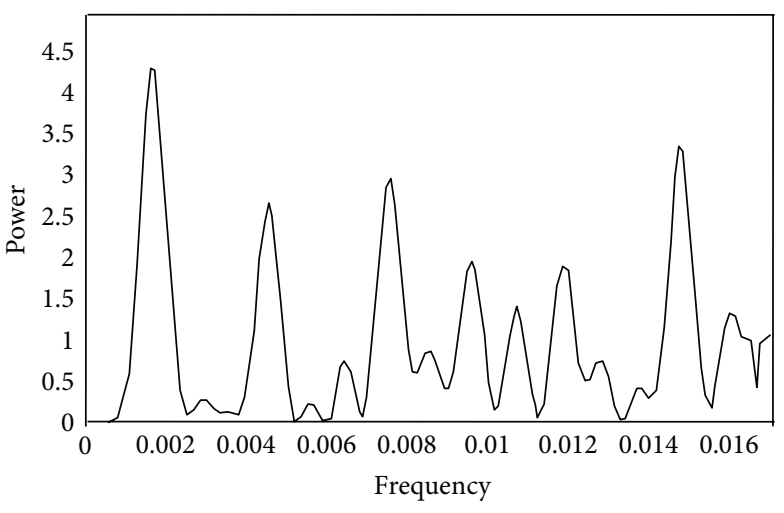

FIGURE 7: Spectral analysis of the magnetic susceptibility at $700^{\circ} \mathrm{C}$ along the core from sebkha Mhabeul.

TABLE 1: Mean, minimum, maximum, and standard deviation values after heating at different temperatures.

\begin{tabular}{lccc}
\hline & $25^{\circ} \mathrm{C}$ & $250^{\circ} \mathrm{C}$ & $700^{\circ} \mathrm{C}$ \\
\hline Mean & 46.0064342 & 47.5064684 & 200.516467 \\
Minimum & 21.9594 & 22.4225 & 53.12956 \\
Maximum & 90.4496 & 94.3186 & 434.4831 \\
Standard deviation & 16.7722996 & 17.7733736 & 82.5223499 \\
\hline
\end{tabular}

increased the variability through the increasing of the standard deviation. Nonetheless, the effect of heating is more pronounced from the passage from $250^{\circ} \mathrm{C}$ to $700^{\circ} \mathrm{C}$.

\section{Conclusion}

The sebkha Mhabeul recorded the climatic variability of the last millennium. Wet climatic periods are marked by high values of the magnetic susceptibility while dry periods are characterized by low values. Added to the subcycles, the spectral analysis shows the individualization of an $888 \mathrm{yr}$ cycle probably related to solar activity. Heating at $250^{\circ} \mathrm{C}$ was not enough to highlight the tephras signals within sediment. Further, it erased the original climatic signal. Subsequently, the spectral analysis does not show any obvious cyclicity. The heating at $700^{\circ} \mathrm{C}$ deepened the loss of the climatic signal. On the other hand, it highlighted the signal of tephras layers, which were observed along the studied core.

\section{Conflict of Interests}

The authors declare that there is no conflict of interests regarding the publication of this paper.

\section{References}

[1] B. C. Deotare, M. D. Kajale, S. N. Rajaguru, S. Kusumgar, A. J. T. Jull, and J. D. Donahue, "Palaeoenvironmental history of Bap-Malar and Kanod playas of western Rajasthan, Thar desert," Proceedings of the Indian Academy of Sciences, Earth and Planetary Sciences, vol. 113, no. 3, pp. 403-425, 2004. 
[2] D. J. Lowe, "Tephrochronology and its application: a review," Quaternary Geochronology, vol. 6, no. 2, pp. 107-153, 2011.

[3] E. Essefi, G. Komatsu, A. G. Fairén, M. A. Chan, and C. Yaich, "Groundwater influence on the aeolian sequence stratigraphy of the Mechertate-Chrita-Sidi El Hani system, Tunisian Sahel: analogies to the wet-dry aeolian sequence stratigraphy at Meridiani Planum, Terby crater, and Gale crater, Mars," Planetary and Space Science, vol. 95, pp. 56-78, 2014.

[4] B. A. Maher and R. Thompson, "Paleorainfall reconstructions from pedogenic magnetic susceptibility variations in the Chinese loess and paleosols," Quaternary Research, vol. 44, no. 3, pp. 383-391, 1995.

[5] B. A. Maher, A. Alekseev, and T. Alekseeva, "Variation of soil magnetism across the Russian steppe: its significance for use of soil magnetism as a palaeorainfall proxy," Quaternary Science Reviews, vol. 21, no. 14-15, pp. 1571-1576, 2002.

[6] J. A. Dearing, I. P. Livingstone, M. D. Bateman, and K. H. White, "Palaeoclimate records from OIS 8.0.-5.4 recorded in loesspalaeosol sequence on the Matmata Plateau, southern Tunisia, based on mineral magnetism and new luminescence dating," Quaternary International, vol. 76-77, pp. 43-56, 2001.

[7] K. A. Nielsen, L. B. Clemmensen, and J. J. Fornós, "Middle Pleistocene magnetostratigraphy and susceptibility stratigraphy: data from a carbonate aeolian system, Mallorca, Western Mediterranean," Quaternary Science Reviews, vol. 23, no. 16-17, pp. 1733-1756, 2004.

[8] E. Aidona and I. Liritzis, "Magnetic susceptibility and radioactivity changes of aegean and ionian sea sediments during last glacial/interglacial: climatic and chronological markers," Journal of Coastal Research, vol. 28, no. 2, pp. 342-353, 2012.

[9] C. S. Feibel, "Tephrostratigraphy and geological context in paleoanthropology," Evolutionary Anthropology, vol. 8, no. 3, pp. 87100, 1999.

[10] R. M. Newnham and D. J. Lowe, "Testing the synchroneity of pollen signals using tephrostratigraphy," Global and Planetary Change, vol. 21, no. 1-3, pp. 113-128, 1999.

[11] A. J. Newton and S. E. Metcalfe, "Tephrochronology of the Toluca Basin, central Mexico," Quaternary Science Reviews, vol. 18, no. 8-9, pp. 1039-1059, 1999.

[12] N. J. Litchfield and K. R. Berryman, "Correlation of fluvial terraces within the Hikurangi Margin, New Zealand: implications for climate and baselevel controls," Geomorphology, vol. 68, no. 3-4, pp. 291-313, 2005.

[13] L. Marquer, S. Pomel, A. Abichou, E. Schulz, D. Kaniewski, and E. van Campo, "Late Holocene high resolution palaeoclimatic reconstruction inferred from Sebkha Mhabeul, southeast Tunisia," Quaternary Research, vol. 70, no. 2, pp. 240-250, 2008.

[14] R. J. Telford, P. Barker, S. Metcalfe, and A. Newton, "Lacustrine responses to tephra deposition: examples from Mexico," Quaternary Science Reviews, vol. 23, no. 23-24, pp. 2337-2353, 2004.

[15] M. J. Gehrels, R. M. Newnham, D. J. Lowe, S. Wynne, Z. J. Hazell, and C. Caseldine, "Towards rapid assay of cryptotephra in peat cores: review and evaluation of various methods," Quaternary International, vol. 178, no. 1, pp. 68-84, 2008.

[16] C. van den Bogaard, W. Dorfler, P. Sandgren, and H.-U. Schmincke, "Correlating the Holocene records: icelandic tephra found in Schleswig-Holstein (Northern Germany)," Naturwissenschaften, vol. 81, no. 12, pp. 554-556, 1994.

[17] F. Oldfield, P. G. Appleby, and R. Thompson, "Palaeoecological studies of lakes in the highlands of Papua New Guinea: I. The chronology of sedimentation," The Journal of Ecology, vol. 68, no. 2, pp. 457-477, 1980.
[18] A. Pawse, S. Beske-Diehl, and S. A. Marshall, "Use of magnetic hysteresis properties and electron spin resonance spectroscopy for the identification of volcanic ash: a preliminary study," Geophysical Journal International, vol. 132, no. 3, pp. 712-720, 1998.

[19] B. Wagner, R. Sulpizio, G. Zanchetta et al., "The last $40 \mathrm{ka}$ tephrostratigraphic record of Lake Ohrid, Albania and Macedonia: a very distal archive for ash dispersal from Italian volcanoes," Journal of Volcanology and Geothermal Research, vol. 177, no. 1, pp. 71-80, 2008.

[20] D. Veres, S. M. Davies, B. Wohlfarth et al., "Age, origin and significance of a new middle MIS 3 tephra horizon identified within a long-core sequence from Les Echets, France," Boreas, vol. 37, no. 3, pp. 434-443, 2008.

[21] C. S. M. Turney, J. J. Lowe, S. M. Davies et al., "Tephrochronology of last termination sequences in Europe: a protocol for improved analytical precision and robust correlation procedures (a joint SCOTAV-INTIMATE proposal)," Journal of Quaternary Science, vol. 19, no. 2, pp. 111-120, 2004.

[22] R. Thompson, R. H. W. Bradshaw, and J. E. Whitley, "The distribution of ash in Icelandic lake sediments and the relative importance of mixing and erosion processes," Journal of Quaternary Science, vol. 1, pp. 3-11, 1986.

[23] E. A. V. Mackie, S. M. Davies, C. S. M. Turney, K. Dobbyn, J. J. Lowe, and P. G. Hill, "The use of magnetic separation techniques to detect basaltic microtephra in last glacial-interglacial transition (LGIT; 15-10 ka cal. BP) sediment sequences in Scotland," Scottish Journal of Geology, vol. 38, no. 1, pp. 21-30, 2002.

[24] F. Stengele and W. Smykatz-Kloss, "Mineralogical and geochemical study of Holocene sebkha sediments in southeastern Tunisia," Chemie der Erde-Geochemistry, vol. 55, no. 4, pp. 241256, 1995.

[25] E. Schulz, W. Smykatz-Kloss, H. Abichou et al., "Zaderg environmental history of the semidesert region in southern Tunisia," Zentralblatt für Geologie und Paläontologie, Teil I, no. 3-4, pp. 423-440, 1995.

[26] E. Schulz, A. Abichou, T. Hachicha, S. Pomel, U. Salzmann, and K. Zouari, "Sebkhas as ecological archives and the vegetation and landscape history of southeastern Tunisia during the last two millennia," Journal of African Earth Sciences, vol. 34, no. 34, pp. 223-229, 2002.

[27] E. Essefi, Multidisciplinary study of Sidi El Hani saline environment: the history and the climatic variability [M.S. thesis], Faculty of sciences of Sfax, University of Sfax, 2009.

[28] E. Essefi, J. Touir, M. A. Tagorti, and C. Yaich, "Record of the climatic variability and the sedimentary dynamics during the last two millennia at Sebkha Dkhila, eastern Tunisia," ISRN Geology, vol. 2013, Article ID 936198, 9 pages, 2013.

[29] E. Essefi, H. Ben Jmaa, J. Touir, M. A. Tagorti, and C. Yaich, "Variability to sedimentary dynamics and climatic conditions during the last two millennia at sebkha souassi in eastern Tunisia," Papers on Global Change, vol. 20, pp. 29-45, 2013.

[30] W. H. Press, S. A. Teukolsky, W. T. Vetterling, and B. P. Flannery, Numerical Recipes in C, Cambridge University Press, New York, NY, USA, 1992.

[31] G. C. Wiles, D. J. Barclay, P. E. Calkin, and T. V. Lowell, "Century to millennial-scale temperature variations for the last two thousand years indicated from glacial geologic records of Southern Alaska," Global and Planetary Change, vol. 60, no. 1-2, pp. 115-125, 2008.

[32] F. McDermott, D. P. Mattey, and C. Hawkesworth, "Centennialscale holocene climate variability revealed by a high-resolution 
speleothem $\delta 180$ record from SW Ireland," Science, vol. 294, no. 5545, pp. 1328-1331, 2001.

[33] M. N. Ross and G. Schubert, "Tidal heating in an internal ocean model of Europa," Nature, vol. 325, no. 6100, pp. 133-134, 1987.

[34] M. H. Carr, M. J. S. Belton, C. R. Chapman et al., "Evidence for a subsurface ocean on Europa," Nature, vol. 391, no. 6665, pp. 363-365, 1998.

[35] P. Yiou, K. Fuhrer, L. D. Meeker, J. Jouzel, S. Johnsen, and P. A. Mayewski, "Paleoclimatic variability inferred from the spectral analysis of Greenland and Antarctic ice-core data," Journal of Geophysical Research, vol. 102, no. 12, pp. 26441-26454, 1997.

[36] M. Stuiver and P. J. Reimer, "Extended ${ }^{14} \mathrm{C}$ data base and revised CALIB $3.0{ }^{14} \mathrm{C}$ age calibration program," Radiocarbon, vol. 35, no. 1, pp. 215-230, 1993.

[37] B. S. Ghuman and R. Lal, "Soil temperature effects of biomass burning in windrows after clearing a tropical rainforest," Field Crops Research, vol. 22, no. 1, pp. 1-10, 1989.

[38] G. Certini, "Effects of fire on properties of forest soils: a review," Oecologia, vol. 143, no. 1, pp. 1-10, 2005.

[39] A. Cohn, "Formation of magnetite nanoparticles by thermal decomposition of iron bearing carbonates: implications for the evidence of fossil life on Mars," Materials ${ }^{*}$ NNIN REU, pp. 5859, 2006.

[40] J. Mignot, M. Khodri, C. Frankignoul, and J. Servonnat, "Volcanic impact on the Atlantic Ocean over the last millennium," Climate of the Past, vol. 7, no. 4, pp. 1439-1455, 2011. 

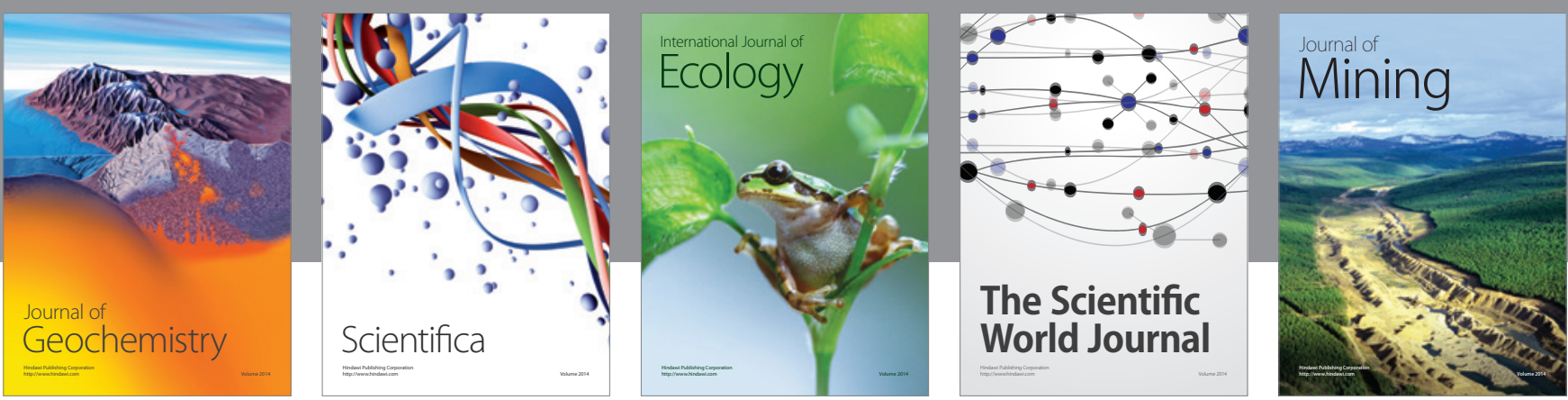

The Scientific World Journal
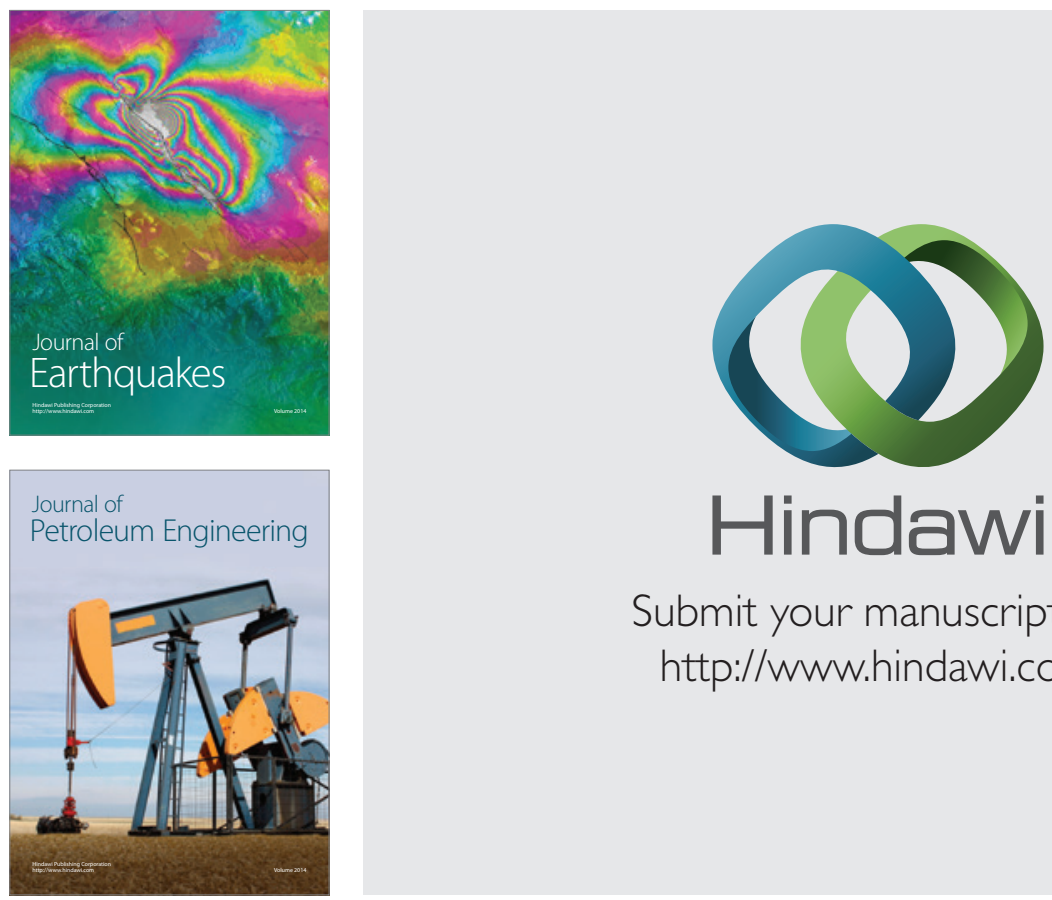

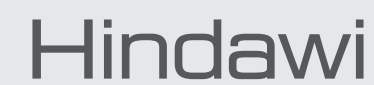

Submit your manuscripts at

http://www.hindawi.com
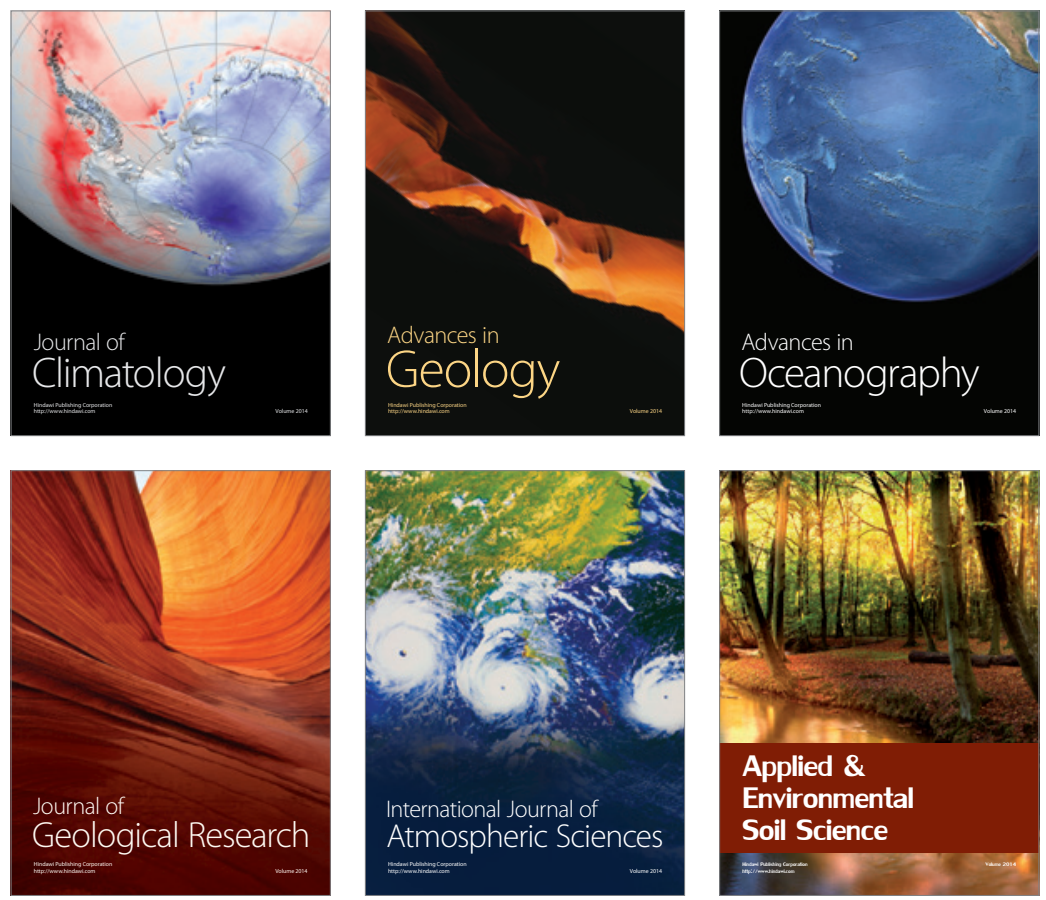
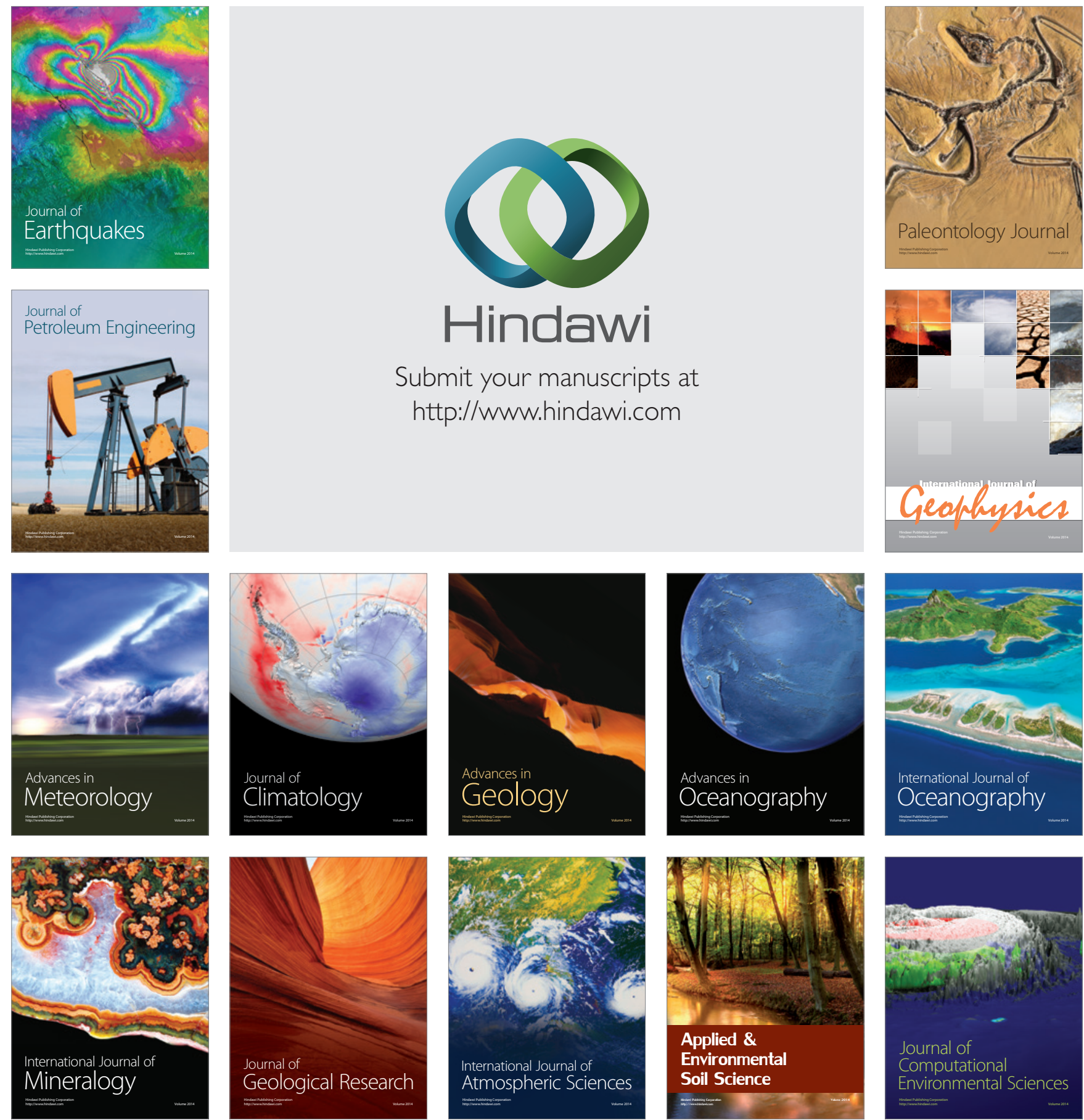